\title{
LEKCJA RELIGII WOBEC EDUKACJI KULTURALNEJ
}

W procesie kształtowania się tożsamości młodego pokolenia ważną rolę odgrywa zarówno nauczanie szkolne, jak i proces edukacji kulturalnej. Proces nauczania jest określony przez obowiązujące programy nauczania, pracę nauczycieli oraz zaangażowanie ucznia w ten proces. Równocześnie dokonuje się edukacja kulturalna. Jest ona dziś dość szeroko rozumiana. Obejmuje dziś ona, zdaniem D. Jankowskiego, trzy różne zakresy: wychowanie estetyczne, edukację humanistyczną i wychowanie do uczestnictwa w kulturze symbolicznej. Wychowanie estetyczne odnosi się do dzieci i młodzieży. W niej akcentuje się rolę szkoły, która ma otworzyć przed wychowankami świat sztuki przez przygotowanie do jej rozumienia i odbioru. Wymaga to kontaktów młodzieży z instytucjami upowszechniania kultury, takimi jak muzea, biblioteki, galerie, filharmonie, teatry itp. Wychowanie estetyczne ogranicza się jednak do zadań realizowanych w tym zakresie na lekcjach języka polskiego i przedmiotach artystycznych. Pomija się $\mathrm{w}$ tej koncepcji aktywność w zakresie przyswojenia sztuki przez ludzi dorosłych ${ }^{1}$.

${ }^{*}$ Ks. dr Kazimierz Skoczylas - adiunkt w Zakładzie Katechetyki i Pedagogiki Religii Wydziału Teologicznego UMK oraz dyrektor Wydziału Katechetycznego Kurii Diecezjalnej Włocławskiej.

${ }^{1}$ D. Jankowski, Edukacja kulturalna, w: Encyklopedia pedagogiczna XXI wieku, red. T. Pilch, t. 1, Warszawa 2003, s. 925-926. 
Edukacja humanistyczna może być postrzegana też jako wprowadzenie jednostki w świat naczelnych, autonomicznych wartości i równocześnie wspieranie jej w kształtowaniu własnej hierarchii wartości, zbieżnej z doświadczeniem ludzkości. Koncentruje się ona albo na ochronie dziedzictwa najszczytniejszych ideałów (nurt racjonalno-laicki) albo na kształtowaniu duchowego wymiaru człowieka według kanonów systemów religijnych świata. Ta edukacja stała się obecnie szczególnie doniosłą powinnością społeczeństw wobec swoich członków. Ma ono obowiązek wspomagać człowieka w wysiłku klasyfikowania systemu uznawanych i odczuwanych wartości. Takie działanie ma pomóc w odnajdywaniu sensu własnego życia i odkrywaniu własnego , ,ja”2

Wychowanie do uczestnictwa w kulturze symbolicznej może korzystać z wychowania estetycznego, z jego przedmiotu i metodyki. Jednak wychowanie estetyczne nie spełnia oczekiwań stawianych dziś przed edukacją kulturalną. Wychowania do uczestnictwa w kulturze wiąże się z faktem kulturalnego rozwoju jednostki. Ten rozwój jest wynikiem działań intencjonalnych, podejmowanych przez rodziców, rodzeństwo, opiekunów, nauczycieli, kapłanów, doradców, instruktorów i inne osoby, ale także działań upowszechnieniowych i animatorskich, prowadzących do sublimacji rzeczywistości doświadczanej w aktywności kulturalnej. Obejmuje ona też doświadczanie wzorów życia i wpływów we własnych środowiskach w toku działalności naukowej i artystycznej, zabawowej i ludycznej. Jest to wychowanie do uczestnictwa w kulturze symbolicznej w toku rozwijanej aktywności kulturalnej. Działania intencjonalne realizowane przez różne podmioty wychowania wyposażają jednostkę w zdolność rozumienia i przeżywania dzieł i wartości kultury symbolicznej. W działalności praktycznej to wychowanie akcentuje różne formy aktywności. W Polsce w okresie powojennym mówiło się o działalności kulturalnej lub działalności kulturalno-oświatowej. Teraz uwagę badaczy skupia animacja kulturalna ${ }^{3}$.

Zatem edukacja kulturalna splata się $\mathrm{w}$ wielu punktach $\mathrm{z}$ procesem nauczania. Jest to szczególnie widoczne w zakresie wychowania estetycznego. W wyniku kontaktu z kulturą udostępnianą przez instytucje upowszechniania kultury tworzy się kultura subiektywna wychowanka. Zostaje on ubogacony wartościami estetycznymi, które mogą inspirować jego rozwój. Jednocześnie przez wychowanie estetyczne zostaje on wyposażony w zdolności do rozumienia treści przekazywanych przez sztukę, wartości, których jest ona nośnikiem. Wiele zaś dzieł sztuki powstało z inspiracji historią zbawienia czy samym tekstem Pisma Świętego. Taka edukacja uprzystępnia również wartości religijne. Mogą one być interioryzowane $\mathrm{w}$ procesie wychowania.

\footnotetext{
2 Tamże, s. 926.

${ }^{3}$ Tamże, s. 927.
} 


\section{KULTURA W NAUCZANIU KOŚCIOłA}

Kościół od początku swego istnienia doceniał znaczenie kultury. W szczególny sposób rozwój jej inspirowało Pismo Święte. Było ono przedmiotem poznania. Treści historii zbawienia inspirowały sztuki plastyczne i prawodawstwo $^{4}$. Zarazem Pismo Święte formowało życie moralne chrześcijan, tworząc ich wewnętrzną kulturę. Szczególnym bodźcem dla rozwoju życia chrześcijańskiego, dla jego nauczania było zetknięcie się z kulturą starożytności. Dzięki świętemu Hieronimowi, Bazylemu Wielkiemu, Grzegorzowi z Nazjanzu oraz św. Augustynowi doszło do stopniowej akceptacji kultury antycznej. W kontakcie z nią stopniowo kształtowała się kultura chrześcijańska ${ }^{5}$. Starożytność pozostawiła po sobie także dorobek myśli filozoficznej. Ona też była poznawana i wykorzystywana do wyrażania nauczania chrześcijańskiego. Stopniowo kształtowała się myśl chrześcijańska znajdująca szczególnie bogaty wyraz w nauczaniu scholastycznym ${ }^{6}$. Przyczyniała się ona także do kształtowania życia duchowego Europy. Szczególnie wielkie dziedzictwo pozostawił po sobie humanizm, zarówno w architekturze, literaturze, szkolnictwie, jak i życiu duchowym. W Kościele coraz wyraźniejsza była świadomość, jaką rolę odgrywa kultura, dlatego też Kościół przez wiele wieków był mecenasem kultury.

Rola kultury została szczególnie wyakcentowana w nauczaniu Kościoła w czasie II Soboru Watykańskiego. Znalazło to niezwykle szeroki oddźwięk przede wszystkim w Konstytucji o Kościele w świecie wspótczesnym. Znajdujemy tam ogólne pojęcie kultury, na które każdy naukowiec mógłby się zgodzić.

Mianem kultury w sensie ogólnym oznacza się to wszystko, czym człowiek doskonali i rozwija wielorakie uzdolnienia swego ducha i ciała; stara się drogą poznania poddać świat pod swoją władzę; czyni bardziej ludzkim życie społeczne tak w rodzinie jak i w całej społeczności państwowej, poprzez postęp obyczajów i instytucji, wreszcie w dziełach swoich w ciągu wieków wyraża, przekazuje i zachowuje wielkie doświadczenia duchowe i dążenia po to, aby służyły postępowi wielu a nawet całej ludzkości (KDK 53).

To określenie posiada kilka charakterystycznych właściwości. Najpierw zauważa się, że tworzywem wszelkiej kultury jest natura, a przede wszystkim człowiek. Wskazuje się także, że celem wszelkiej kultury jest doskonalenie natury człowieka przez rozwijanie uzdolnień jego ducha i ciała. Ten cel nie ogranicza się tylko do pojedynczego człowieka. Kultura ma przede wszystkim

${ }^{4}$ Por. F.W. Bednarski, Teologia kultury, Kraków 2000, s. 35-50.

${ }^{5}$ Tamże, s. 51-72; zob. także S. Kot, Historia wychowania, Warszawa 1996, wyd. 3, s. $118-127$.

${ }^{6}$ Tamże, s. 73-98. 
doskonalić życie społeczne i czynić je bardziej ludzkim. Podkreśla się też, że sprawcą kultury jest człowiek, przede wszystkim przez swoje rozumne działanie. Dokonuje się to przez wykonywaną przez niego pracę umysłową, artystyczną, fizyczną, a nade wszystko przez jego działania moralne. Kościół w swoim nauczaniu dostrzega, że kultura ma charakter historyczny. Oznacza to, że jest ona zależna od konkretnych warunków życia ludzkiego ${ }^{7}$. Sobór uwypukla też specyficzne właściwości kultury. Zauważa się, że ludzkość dysponuje wielkimi możliwościami gospodarczymi, a jednocześnie jej część cierpi głód. Towarzyszy jej wielkie wyczulenie na wolność, a równocześnie w tym samym czasie powstają różne formy niewoli społecznej i psychicznej. Społeczność międzynarodowa głęboko odczuwa swoją jedność, a zarazem jest ona rozrywana przez gwałtownie zwalczające się siły. Poszukuje się coraz doskonalszego porządku doczesnego. Nie towarzyszy temu jednocześnie wzmożone staranie o rozwój duchowy. Rozwija się społeczeństwo przemysłowe, które radykalnie zmienia warunki życia. Upowszechnia się cywilizacja miejska i temu towarzyszy zwielokrotnienie więzi łączących człowieka z innymi. Zmiana umysłowości powoduje jednocześnie zakwestionowanie, szczególnie przez młodych, wartości otrzymanych ${ }^{8}$.

Stosunek Kościoła do kultury znajduje wyraz także w Katechizmie Kościoła Katolickiego, który został zatwierdzony przez Jana Pawła II. Zauważa się, że rozwijanie kultury należy do zadań misyjnych Kościoła. Kościół głosi Ewangelię oraz rozwija proces inkulturacji, aby wcielać Ewangelię w kultury narodów (por. KKK 854). Rozwojowi kultury powinno sprzyjać tworzenie takich warunków życia publicznego, które pozwalają na wprowadzenie w życie społeczne sprawiedliwości (por. KKK 909). Stąd przedmiotem troski Kościoła jest, aby człowiek był sprawiedliwie wynagradzany za pracę (por. KKK 2434). Katechizm zwraca również uwagę, że wiara tworzy kulturę. Znajduje ona wyraz w życiu moralnym chrześcijan (por. KKK 2343), a także w liturgii Kościoła. „Ona [liturgia] przyjmuje i uświęca elementy stworzenia i kultury ludowej” (KKK 1149). Ona także dochodzi do głosu w modlitwie. Kościół proponuje wiernym, zgodnie z kontekstem liturgicznym, społecznym i kulturalnym, język modlitwy, który zawiera słowa, melodie, gesty, ikonografię. Jest to wyrazem kultury duchowej Kościoła (por. KKK 2663).

Problematyka kultury była często obecna w nauczaniu papieża Jana Pawła II. W wielu swoich wypowiedziach odwoływał się do nauczania Kościoła, a zwłaszcza do nauczania o kulturze Soboru Watykańskiego II. Podkreślał, że

Człowiek żyje prawdziwym ludzkim życiem dzięki kulturze. Jego życie jest kulturą również w tym znaczeniu, że poprzez nią człowiek odznacza

\footnotetext{
7 Tamże, s. 102-106.
}

${ }^{8}$ Tamże, s. 106-107. 
się i odróżnia się od całej reszty istnień wchodzących w skład widzialnego świata: Człowiek nie może się obejść bez kultury. Kultura jest właściwym sposobem istnienia i bytowania człowieka9 .

Mówiąc o człowieku, podkreśla, że jest on nie tylko sprawcą swego działania, ale też jego twórcą. Owocami tej twórczości są dobra zaspokajające potrzeby ludzkie. Zatem wynikiem tej twórczości są wartości umożliwiające lub ułatwiające osiągnięcie prawdy, dobra i piękna.

Papież interesuje się człowiekiem jako twórcą kultury. Dla chrześcijanina tworzącego kulturę ważne jest rozumienie własnej tożsamości. W wielu wypowiedziach podkreśla, nawiązując do Biblii, że człowiek jest obrazem Boga.

Kiedy mówi się o człowieku jako o obrazie Boga, daje się do poznania, że nie na drodze podobieństwa do przyrody leży odpowiedź na tajemnicę człowieczeństwa. Człowiek jest bardziej podobny do Boga niż do przyrody: Człowiek bowiem otrzymawszy przykazanie Boże, by „zaludnić ziemię i uczynić ją sobie poddaną" (Rdz 1,28), przynależąc do widzialnego świata, do przyrody, równocześnie jakoś różni się od tej przyrody; świat widzialny jest dla niego, a on nad nim „panuje”. Panuje zaś w oparciu o to, kim sam jest, o siły i władze duchowej natury, które odróżniają go od przyrody (RH 12).

On też uwypukla konieczność stworzenia właściwych warunków, aby człowiek mógł tworzyć kulturę. Eksponuje tu zapewnienie osobie ludzkiej wolności, uwolnienie jej od głodu, chorób, nędzy, a także przemocy ${ }^{10}$.

Kultura, będąc doskonaleniem życia ludzkiego, powstaje przez tworzenie wartości zaspokajających potrzeby życia ludzkiego. Można wiec powiedzieć, że powstaje ona $w$ trakcie wykonywania pracy i jest też owocem tworzonym przez pracę. Szczególnie wyraźnie zostało to podkreślone w jego encyklice Laborem exercens. Papież uwypukla tam, że człowiek powołany jest do pracy i ona wyróżnia go pośród reszty stworzeń. Przez pracę człowiek nie tylko wytwarza dobra, ale sam staje się bardziej człowiekiem, spełnia się w swym człowieczeństwie (por. LE 5-7). Praca to nie tylko wytwarzanie dóbr wartościowych do zaspokajania potrzeb cielesnych, ale to także tworzenie wartości duchowych, artystycznych, wartości umysłowych takich jak nauka, lecz także wartości religijno-moralnych ${ }^{11}$.

Szczególnie mocno eksponowana jest przez papieża kultura religijno-moralna. On wielokrotnie podkreśla konieczność „bardziej być nad bardziej mieć”.

\footnotetext{
${ }^{9}$ Por. K. Wojtyła, Osoba i czyn, Kraków 1969, s. 162.

${ }^{10}$ Por. F.W. Bednarski, dz. cyt., s. 130-131.

${ }^{11}$ Tamże, s. 137.
} 
W encyklice Redemtor hominis przypomniał, że „rozwój techniki oraz naznaczony panowaniem techniki rozwój cywilizacji współczesnej domaga się proporcjonalnego rozwoju moralności i etyki" (RH 15). W wielu wypowiedziach podkreślał, że istotą tej kultury są podstawowe sprawności moralne, tzn. roztropność, sprawiedliwość, umiarkowanie i męstwo. Z tymi podstawowymi cnotami musi się jego zdaniem łączyć miłość. W spotkaniu z młodzieżą akademicką Rzymu wyakcentował stale podnoszenie kultury ogólnej każdego chrześcijanina. Mówił wtedy „do formacji naukowej trzeba dodać rzetelną formację moralną i chrześcijańską, potwierdzoną życiem - formację, która doprowadziłaby do coraz bardziej harmonijnej syntezy między wiarą a rozumem, wiarą a kultura, wiarą a życiem"12.

Wraz z kulturą osoby musi rozwijać się kultura społeczna. Wyraża się ona w przestrzeganiu sprawiedliwości społecznej oraz w trosce o tych, którzy pozbawieni są dóbr duchowych lub materialnych. Takie odniesienie do tych osób wynika z faktu godności osoby ludzkiej ${ }^{13}$. Kultura zaś w stosunkach międzynarodowych oznacza wykluczenie wojny. „Nigdy jeden naród nie może rozwijać się za cenę drugiego, za cenę jego uzależnienia, podboju, zniewolenia, za cenę jego eksploatacji, za cenę jego śmierci"14.

Ojciec Święty rozumiał wielką wagę kultury dla życia chrześcijańskiego. Miał także świadomość wielu zagrożeń, jakie dla wiary niesie współczesna kultura. Stąd też w 1982 roku powołał Papieską Radę do spraw Kultury. Jej zadaniem jest sprzyjać dialogowi Kościoła z innymi kulturami, w tym z religiami niechrześcijańskimi. Efektem tego dialogu ma być dobra orientacja Stolicy Apostolskiej wobec wielkich dążeń współczesnego świata. Do zadań tej Rady należy też obserwacja tego, co dzieje się w świecie kultury oraz uczestniczenie w określonych przedsięwzięciach kulturalnych, a także animowanie działań w tym zakresie. Powinna ona także nawiązywać współpracę z UNESCO i Radą Europy $^{15}$. Działalność tej Rady zwiększyła liczbę kontaktów Kościoła z międzynarodowymi instytucjami kultury. Już od chwili jej powołania Stolica Apostolska, za jej pośrednictwem, uczestniczyła w kreowaniu wielu wydarzeń kulturalnych. Dużej intensywności nabrały również jej kontakty z religiami niechrześcijańskimi, podjęto wiele badań nad problemem inkulturacji Ewangelii oraz przyczynami ateizmu. Zaowocowało to licznymi publikacjami naukowymi. Stolica Apostolska zyskała pełniejszy obraz współczesnych tendencji w kulturze światowej ${ }^{16}$.

${ }^{12}$ Jan Pawet II. Przemówienie do młodzieży akademickiej w Rzymie 5 IV 1979, w: Jan Pawet II do Ludu Bożego, Watykan 1979, s. 130.

${ }^{13}$ Tamże, s. 11.

${ }^{14}$ Jan Pawet II. Pielgrzymka do Ojczyzny, Warszawa 1979, s. 238-239.

${ }^{15}$ J. Kulska, Miejsce Papieskiej Rady do spraw Kultury w międzynarodowych stosunkach kulturalnych, w: Drogi i rozdroża kultury chrześcijańskiej Europy, red. U. Cierniak, J. Grabowski, Częstochowa 2003, s. 115-116.

${ }^{16}$ Tamże, s. 118-124. 
Kultura jest szczególnie istotna w procesie wychowania. Zwrócił na to uwage Jan Paweł II, przemawiając do UNESCO. Powiedział wtedy:

pierwszym i zasadniczym zadaniem kultury jest wychowanie. W wychowaniu chodzi właśnie o to, aby człowiek stawał się coraz bardziej człowiekiem - o to, by bardziej był, a nie o to, by więcej miał - aby więc przez wszystko co ma, co posiada, umiał bardziej być i pełniej być człowiekiem - to znaczy, by również umiał być nie tylko z drugimi, ale dla drugich ${ }^{17}$.

W dziele wychowania uczestniczy również katecheza. W zamyśle Kościoła ma ona być tym miejscem, w którym dokonuje się zakorzenienie Ewangelii w różnych kulturach. Zadaniem zaś katechezy w tym zakresie jest inkulturacja (por. CT 53). Realizując to zadanie, musi brać pod uwagę zasady, które powinny być zachowane w procesie wcielania wiary w różne kultury. Pierwszą jest zasada niezależności od kultur. Przyjmuje ona, że wiara chrześcijańska nie identyfikuje się z żadną kulturą. Może zatem wcielać się we wszystkie kultu$\mathrm{ry}^{18}$. Następną zasadą jest wcielanie się w kultury. Orędzie chrześcijańskie od swego początku wciela się $\mathrm{w}$ różne kultury. To orędzie nie występuje $\mathrm{w}$ stanie czystym, ale zawsze jest związane licznymi relacjami z kulturą. Zarazem jego wcielenie w kultury jest warunkiem jego przeżycia, pogłębienia i przekazania ${ }^{19}$. Trzecią zasadą jest zasada profetycznego demaskowania. Określa ona, że wiara chrześcijańska przejmuje w odniesieniu do kultur funkcję ujawniania oraz uzdrawiania i przekształcania tych kryteriów, sposobów myślenia lub stylów życia, jakie są sprzeczne z Królestwem Bożym (por. DOK 109). Wiara demaskuje w kulturach obecność grzechu i usuwa z kultur to, co określa się jako fałszywe wartości. Na tym polega funkcja profetyczna wiary, która wyraża się w demaskowaniu zła ${ }^{20}$. Do tych zasad należy też zasada koła hermeneutycznego. Kultury są bowiem koniecznym narzędziem do ponownego wyrażenia orędzia Słowa Bożego. Przekazując orędzie, trzeba wziąć pod uwagę zarówno sformułowania pochodzące z przeszłości, jak również to, na ile nadają się one do wyrażenia tego dziedzictwa dla ludzi żyjących we współczesnej kulturze ${ }^{21}$.

Urzeczywistnianie procesu zakorzeniania się wiary w różnych kulturach napotyka na różne trudności. W ciągu wieków wiara chrześcijańska związała się najmocniej z kulturą europejską. To doprowadziło do tego, że najczęściej wiara była zwiastowana nowym narodom w szacie kultury europejskiej. Miało

${ }^{17}$ Jan Pawet II. Przemówienie w UNESCO, Watykan, s. 10.

${ }^{18}$ Por. E. Alberich, Katecheza dzisiaj. Podręcznik katechetyki fundamentalnej, Warszawa 2003, s. 101.

${ }^{19}$ Tamże, s. 101.

${ }^{20}$ Tamże, s. 102.

${ }^{21}$ Tamże, s. 102. 
to różne następstwa. W Ameryce Łacińskiej za podbojem jej przez Hiszpanów postępowali misjonarze. Tam ewangelizacja była odczytywana jako element pogłębiający zależność od kolonizatorów. Nie była ona dobrowolnym przyjęciem orędzia Ewangelii, ale formą nacisku. To zaś czyniło ją dość dwuznaczną ${ }^{22}$.

Kolejną trudnością dla katechezy jest znalezienie właściwego języka dostosowanego do przekazu wiary. Chodzi w nim nie tylko o znalezienie właściwej szaty słownej, ale także przedstawienie w nim właściwego rozumienia i poprawnej interpretacji orędzia chrześcijańskiego. Jego rolą jest pomóc wyrazić wiarę w sposób zrozumiały w danej kulturze. W przeszłości, zdaniem Albericha, katecheza zajmowała się zbyt często precyzją doktrynalną i teologiczną, a zapominała o tym, że przekaz wiary musi mieć znaczenie dla odbiorców, aby był przyjęty ${ }^{23}$.

Problem inkulturacji Słowa Bożego dostrzega też Polskie Dyrektorium Katechetyczne Kościoła Katolickiego. Katecheza, podkreśla to Dyrektorium, ma uczyć dostrzegać w Słowie Bożym Chrystusa i zarazem patrzeć na Biblię jako na słowo ludzkie, które jest filarem kultury europejskiej. Takie odniesienie jest konieczne, aby na katechezie nie dochodziło do przeciwstawienia kultury Objawieniu Bożemu ${ }^{24}$. Katecheza w Polsce winna też, jak uwypukla to Dyrektorium, przekazywać orędzie zbawienia w kontekście kultury narodowej i historii narodu polskiego. Jej rolą jest także pełnić funkcję krytyczną wobec kultury. Nie każda bowiem kultura jest możliwa do przyjęcia przez wiarę. To odnosi się do kultury zaprzeczającej prawdzie lub też do takiej, która prowadzi do negacji Kościoła i wiary ${ }^{25}$.

\section{ZNACZENIE KULTURY POLSKIEJ DLA INKULTURACJI WIARY}

Zgodnie z Dyrektorium Katechetycznym Kościoła Katolickiego w Polsce, katecheza, przekazując orędzie zbawienia, powinna odwoływać się do kultury narodowej i historii narodu polskiego. Trzeba zauważyć, że kultura polska jest wytworem wielu grup społecznych funkcjonujących w społeczeństwie polskim. Szczególne znaczenie w niej odgrywały elity społeczne. Największy wkład na przestrzeni wieków w ukształtowanie się tej kultury wniosła polska szlachta. Są w niej również zawarte elementy wytworzone przez wszystkie pozostałe grupy społeczne.

Z kolei grupą społeczną, który gromadzi w swoim wnętrzu różne mniejsze grupy społeczne, jest naród. Naród charakteryzuje przekonanie o po-

${ }^{22}$ Tamże, s. 103.

${ }^{23}$ Tamże, s. 105.

${ }^{24}$ Konferencja Episkopatu Polski. Dyrektorium Katechetyczne Kościoła Katolickiego w Polsce, Kraków 2001, s. 57.

${ }^{25}$ Tamże, s. 58. 
chodzeniu od wspólnego przodka i przekonanie o więzach krwi. Z tym wiążą się pozytywne postawy wobec własnego narodu jako całości i poszczególnych członków. Naród posiada też wspólny język, który stwarza możliwość swobodnej komunikacji. Posiada on też swoje terytorium albo przynajmniej dominuje na nim. Do jego dziedzictwa należą także wspólne dzieje i wspólny dorobek w postaci praw, wierzeń, strojów, budowli czy utworów literackich. On posiada też wspólny los i wspólne przeżycia. Niekiedy przekonany jest również o swojej szczególnej misji ${ }^{26}$.

Właściwości kultury narodowej dobrze charakteryzuje centrum kultury. W nim istotne są wartości. Stanowią one o specyfice kultury danego społeczeństwa. Przez jednych nazywane są wartościami podstawowymi, naczelnymi lub centralnymi. Inni nazywają je wiodącymi, dominującymi lub rdzennymi. Wartości centralne to te, które są powszechnie akceptowane w danym społeczeństwie i są podstawą organizacji systemu społecznego, i tożsamości kulturowej. Ich usunięcie prowadzi do rozbicia systemu społecznego, a nawet zaniku samej kultury. Dzięki tym wartościom grupy społeczne mogą zachować własną kulturę i być żywotne i kreatywne w ramach swojej kultury. Wokół takich wartości koncentrują się: idee i ideały etyczne, społeczne, religijne i polityczne, wierzenia, normy, prawo, systemy organizacji, zarządzania, pracy, twórczość artystyczna, działalność jednostek i grup, utwory literackie, pieśni, miejsca kultu religijnego i pamięci narodowej, budowle. Są to różnorodne wytwory kulturowe, w których utrwalają się wartości ${ }^{27}$.

Z tymi wartościami wiążą się specyficzne stany psychiczne jednostek, czyli wzory reakcji uczuciowych, struktury myślenia i postawy wobec własnej grupy narodowej i innych grup etnicznych. Szczególnie ważne jest to, że wartości centralne, utrwalające je wytwory kulturowe i stany psychiczne jednostek tworzą centrum kultury. Centrum kultury kształtuje się przez całą historię danego społeczeństwa. Ono wyznacza swoiste widzenie przeszłości, teraźniejszości i przyszłości danego społeczeństwa. W jego świetle jednostki oceniają to, co nowe i obce, procesy wewnętrzne i zmiany zachodzące w innych społeczeństwach. Ono decyduje o tym, co z obcej kultury będzie przyjęte, a co zostanie odrzucone. Specyficzną cechą jego jest to, że trudno określić, które jego elementy są ważniejsze. Istotą tak rozumianego centrum są nade wszystko wartości. Całość centrum jest elastyczna. Raz jedne, a raz inne elementy dochodzą w nim do głosu. Kiedy np. zagrożona jest samodzielność społeczeństwa, na czoło wysuwa się wolność i suwerenność. Wokół nich koncentrują się inne wartości. Gdy pojawia się zagrożenie, wówczas całe centrum się ożywia ${ }^{28}$.

\footnotetext{
${ }^{26}$ L. Dyczewski, Kultura polska w procesie przemian, Lublin 1993, s. 46.

${ }^{27}$ Tamże, s. 60-61.

${ }^{28}$ Tamże, s. 61-62.
} 
Najważniejszymi wartościami centrum kultury polskiej, zdaniem Dyczewskiego, są: 1) rodzina, rodzinność, dom; 2) wspólnotowość, poczucie wspólnoty; 3) umiłowanie dziecka i ważna rola kobiety; 4) wrażliwość na wartości transcendentne i na sacrum, religijność; 5) irracjonalizm, uczuciowość, romantyzm; 6) wewnętrzna wolność, osobista godność, honor indywidualizm; 7) zdolność przebaczenia, brak mściwości i okrucieństwa; 8) gościnność, towarzyskość, hojność; 9) gotowość do poświęceń i ofiary, poczucie służby; 10) umiłowanie wolności, patriotyzm; 11) optymizm, nadzieja wbrew nadziei; 12) otwartość na inne kultury, tolerancja, uniwersalizm; 13) szacunek dla pracy twórczej; 14) demokracja, obywatelskość i krytycyzm wobec władzy ${ }^{29}$.

Z kolei do wytworów kulturowych istniejących w centrum naszej kultury należą: język polski, orzeł w koronie, flaga narodowa; wydarzenia takie jak chrzest Polski, bitwa pod Grunwaldem, unia polsko-litewska; walka o trwanie narodu w czasie zaborów, walka bez przemocy z reżimem komunistycznym; miejsca kultu religijnego i pamięci narodowej; epopeje narodowe Mickiewicza i Sienkiewicza; twórczość wielkich artystów, jak Jan Matejko, Fryderyk Chopin, Stanisław Wyspiański; postacie historyczne, jak Kościuszko, Piłsudski, Maksymilian Kolbe, Jan Paweł II; obrzędy i zwyczaje roku polskiego, przede wszystkim Bożego Narodzenia, Wielkanocy, Wszystkich Świętych i Dnia Zadusznego, a także śluby i imieniny ${ }^{30}$.

W polskiej kulturze narodowej uwypuklone jest znaczenie rodziny. Ona korzysta z tej kultury, ale również sama tworzy kulturę. Rodzina, chcąc normalnie funkcjonować, przyjmuje z kultury społeczeństwa podstawowe wartości, normy, wzory zachowań, historię, przestrzega obowiązujących praw, obyczajów i świąt, korzysta z funkcjonujących instytucji. Całe to dziedzictwo kulturowe może ona wykorzystać do swego funkcjonowania i może je przekazać nowemu pokoleniu, które stopniowo utożsamia się ze społeczeństwem. Rodzina w ten sposób staje się fundamentem ciągłości kulturowej społeczeństwa i zapewnia trwanie tej kultury. Zarazem ta sama rodzina w życiu domowym może pielęgnować wytwory kultury i wzory zachowań, które są odmienne w stosunku do kultury społeczeństwa. $Z$ tego powodu rodziny mogą się cieszyć uznaniem społeczeństwa, ale mogą też być lekceważone, a nawet zwalczane. Kultura rodziny może stawać mniej lub bardziej odrębna od kultury społeczeństwa. W rodzinie może występować swoista dwukulturowość. Rodziny najczęściej w życiu domowym pielęgnują kulturę grupy etnicznej lub religijnej ${ }^{31}$.

Charakterystyczną właściwością rodziny jest to, że w oparciu o uznane wartości ocenia nowe treści kulturowe i jedne przyjmuje, a inne odrzuca. Pełni

\footnotetext{
${ }^{29}$ Tamże, s. 64.

${ }^{30}$ Tamże, s. 65.

${ }^{31}$ L. Dyczewski, Rodzina twórca i przekazicielem kultury, Lublin 2003, s. 30-32.
} 
ona rolę swoistego filtra dla różnych treści kulturowych. Dzięki temu ma szanse przekazać istotne wartości rodzimej kultury i zarazem bronić podważanych wartości w świadomości młodego pokolenia. Dzięki tej właściwości rodziny polski naród mógł bronić swojej tożsamości i swojej kultury w czasie niewoli narodowej, podczas drugiej wojny światowej czy w czasach komunizmu ${ }^{32}$. Rodzina polska jest w znaczącej części rodziną katolicką. Ma zatem ona istotne znaczenie dla przekazania wartości ważnych dla chrześcijaństwa. Może także ich bronić w świadomości młodego pokolenia. Do tych właściwości można zaliczyć: kształtowanie właściwości poznania i rozumienia, włączanie w działanie, wprowadzanie w świat znaczeń, ochranianie przed niekorzystnymi czynnikami świata zewnętrznego.

Rodzina kształtuje u swoich członków, przede wszystkim wśród dzieci, umiejętność postrzegania rzeczywistości, widzenia problemów, stawiania pytań i szukania odpowiedzi. Wpływa na styl tego, co jest poznawane. Ważne jest w niej kształtowanie postawy ku dobru, pięknu i prawdzie. Ona także kształtuje obraz człowieka, obraz świata i życia społecznego ${ }^{33}$.

Rodzina wprowadza także w świat znaczeń. Rzeczywistość jest dla człowieka skomplikowana. Stąd w rodzinie jest ona nieustannie poznawana i nazywana. Wszystko ma swoją nazwę. Oprócz świata poznawanego zmysłami istnieje świat wytworzony przez człowieka, świat znaczeń. Poznanie świata znaczeń jest kluczem do poznania świata zewnętrznego i siebie samego. Za pomocą poznanych znaczeń opisujemy świat zewnętrzny, przedstawiamy swoje myśli, przeżycia, porozumiewamy się z innymi, tworzymy więzi społeczne i kształtujemy także świat zewnętrzny. Człowiek zaś pragnie poznać świat znaczeń. Pierwszymi, którzy wprowadzają w ten świat, są rodzice i rodzeństwo. Ten świat przyswajany przez dziecko może być mniej lub bardziej bogaty. Uwidacznia się to $w$ języku dziecka. Wprowadzenie w świat znaczeń w rodzinie dokonuje się zazwyczaj spontanicznie, przez uczestnictwo w wydarzeniach życia rodzinnego. Ona, wprowadzając w ten świat, spełnia rolę odźwiernego do świata kultury swojej grupy społecznej, grupy religijnej, etnicznej i szerszych kręgów kulturowych ${ }^{34}$.

Rodzina też ochrania swoich członków przed niekorzystnymi czynnikami świata zewnętrznego. Dokonuje pewnej redukcji świata zewnętrznego. Dzięki temu świat zewnętrzny przedstawia się jako bardziej zrozumiały i pozytywny. Pełni ona też rolę interpretatora świata zewnętrznego. Przez to dzieci chętniej poznają ten świat i mają do niego bardziej pozytywny stosunek. Jeśli ona nieumiejętnie wprowadza w sens świata znaczeń, to dzieci go często nie rozumieją ${ }^{35}$.

\footnotetext{
32 Tamże, s. 14-19.

33 Tamże, s. 33-34.

${ }^{34}$ Tamże, s. 35-36.

35 Tamże, s. 37.
} 
Rodzina najpierw włącza swoich członków, szczególnie najmłodszych, w kulturę narodową, ogólnospołeczną i tych kręgów kulturowych, z którymi jest związana. Następnie, tworząc i rozwijając własną kulturę, stanowi dla swoich członków naturalne i podstawowe środowisko kształtowania własnego systemu wartości, norm i wzorów zachowań. Ona też zapewnia kontynuację dziedzictwa kulturowego, stabilizuje innowacje kulturalne i wzmacnia pluralizm kulturowy. Często stanowi schronienie dla dziedzictwa kulturowego, które jest pomijane lub lekceważone przez kulturę dominującą. Dawnym wartościom nadaje też nowe interpretacje. Tym samym wyhamowuje tempo zmian kulturowych w społeczeństwie. Zapewnia też społeczeństwu kontynuację kultury. Jest ona także regulatorem dyfuzji kulturowej. Rodzina, będąc w centrum wydarzeń politycznych, społecznych, zajmuje wobec nich postawę aktywną. Jedne elementy akceptuje i wszczepia w swoje życie, wobec innych zaś zachowuje dystans albo je wręcz odrzuca ${ }^{36}$.

Kultura narodowa w Polsce czerpie obficie także z kultury ludowej. Czerpie z niej także rodzina tworząca swoją kulturę. Kulturę ludową charakteryzuje, zdaniem D. Simonides, specyficzny stosunek do ziemi, do „małej ojczyzny; stosunek do drugiego człowieka, stosunek do Boga i stosunek do pracy ${ }^{37}$.

Stosunek do ziemi wiąże się z typem więzi społecznej, który znamionuje lokalną społeczność. Więź ta jest oparta na bezpośredniej znajomości, na poszanowaniu własnych poglądów. Każdy typ więzi, jak zauważa to D. Simonides, realizuje się $\mathrm{w}$ obrębie wyznaczonego terytorium. Terytorium to zostaje przez tę społeczność zawłaszczone i zadomowione. Wszystko winno być w nim zrozumiałe, bliskie i swojskie. Powinno mieć też swoją nazwę. Takim terytorium jest „mała ojczyzna”. Rozumie się przez nią najbliższe człowiekowi otoczenie, najbliżej ukształtowany krajobraz, przestrzeń, którą człowiek może ogarnąć swoimi oczami. Zatem „mała ojczyzna” dla ludności wiejskiej to była przestrzeń widziana z perspektywy własnego domu. Do tej przestrzeni należała własna zagroda, rzeczka przepływająca przez wioskę, groby przodków i kościól ${ }^{38}$. Trzeba też mieć świadomość, że po roku 1945 wiele milionów ludzi utraciło swoją małą ojczyznę. Ten proces dotknął przede wszystkim przesiedleńców. Aby normalnie żyć, ludzie musieli na nowo oswajać nową przestrzeń. Było to dla nich jednak bardzo trudne. W takiej sytuacji nowego znaczenia nabrała więź regionalna i mała ojczyzna. Tym samym większe znaczenie zyskały wspólne tradycyjne wartości, które dla określonej grupy były jej własnymi wartościami. Można więc mówić o wspólnych wartościach i więziach łączących tamtych

36 Tamże, s. 39-41.

${ }^{37}$ D. Simonides, Źródta ludowe i regionalne w polskiej kulturze, w: Kultura polska w nowej sytuacji historycznej, Warszawa 1998, s. 83.

${ }^{38}$ Tamże, s. 84-85. 
ludzi. „Trwałym podłożem dla takich więzi może być wspólna gwara, strój, obyczaj i zwyczaj" ${ }^{\prime 39}$.

Drugim znamiennym rysem kultury ludowej jest stosunek do człowieka. W tej kulturze znamienny jest bezpośredni kontakt osoby z osobą. W niej ludzie byli nakierowani na siebie, na dzielenie się ze sobą wiadomościami, ale też i dobrami. Wyrażało się to choćby w obrzędach dzielenia się opłatkiem, dzielenia się jajkiem, witaniu chlebem i solą, pozostawianiem snopów i ziaren na polu dla biednych czy ustawianiem pustego nakrycia na stole w czasie Wigilii. Był to widoczny dla wszystkich domowników wyraz pamięci o innych. Przejawem bliskości kontaktu był zwyczaj pozdrawiania spotkanego człowieka, odwiedzania matki po urodzeniu dziecka czy życzenia pomyślnych plonów. Można więc powiedzieć, że najgłębszy sens tej kultury tkwił w dostarczeniu członkom społeczności wiejskiej poczucia psychicznej stabilizacji i głębokiego przekonania, że nawet $\mathrm{w}$ największych trudnościach mogę liczyć na pomoc ze strony tej wspólnoty ${ }^{40}$. Znamiennym więc przejawem stosunku człowieka do człowieka była wiejska solidarność.

Kolejnym przejawem kultury ludowej jest stosunek do Boga. To odniesienie głębiej angażuje psychikę człowieka. Stąd ludzie bardziej utożsamiają się z wyznawaną wiarą niż z narodem. Stąd częstsze w kulturze ludowej trzymanie się wiary ojców. Zarazem kto ma wiarę ojców, ten jest też wierny swojej ojczyźnie. Religijne odniesienie ujawnia się także w każdym działaniu. Dlatego tak eksponuje się tu religijne przywiązanie do ziemi, a zwłaszcza do Pana Boga i jego świętych. W tej kulturze bardzo silnie zakorzenione jest przekonanie, że Pan Bóg jest Panem wszechświata i wszystko, co dzieje się na świecie, dzieje się za Jego przyzwoleniem. Równie mocno wieś identyfikowała się z przekonaniem, że człowiek jest stworzony, aby wypełnić swoje zadanie i przeżyć swoje życie uczciwie i by wybierać dobro. Człowiek wyrosły w tej kulturze czuł się częścią antropokosmosu. Miał głęboką wiedzę o księżycu i gwiazdach. Wiedział, jak się zachować w czasie nowiu księżyca, wiedział, kiedy nadejdzie burza i kiedy trzeba skosić trawę. Takie całościowe spostrzeganie przyrody, odbieranie bodźców dochodzących z otaczającego świata, dostarczało jednostce i grupie przekonania, że jeśli zastosuje się do ustalonych sposobów zachowania, to ani jemu, ani grupie, w której żyje, nic złego się nie stanie. $Z$ tym światem stworzonym łączyła się głęboko zakodowana odpowiedzialność za świat. Zdaniem Simonides istnieją w kulturze liczne inwokacje do zjawisk przyrody, które obrazują głęboki szacunek do niej ${ }^{41}$.

\footnotetext{
${ }^{39}$ Tamże, s. 85.

${ }^{40}$ Tamże, s. 86.

41 Tamże, s. 87-89.
} 
Dalszym elementem opisującym właściwości kultury ludowej jest stosunek do pracy. Jest to zdecydowanie inny stosunek niż w kulturze szlacheckiej. Kultura szlachecka nie ceniła pracy, miała ją często w pogardzie. Tymczasem w kulturze ludowej praca jest szczególnie ceniona. Praca jest w niej elementem uświęcającym życie. Dlatego ziemia, którą lud uprawiał, jest swoistym sacrum, które wymaga pielęgnacji i opieki. Ziemia jest też w pieśniach i opowieściach najbardziej czule określana. Aby uprosić u Pana Boga jej urodzajność, idą procesje na pola. Etos pracy w kulturze ludowej przejawia się też szacunkiem rolnika do narzędzi pracy. Wiele jest opowieści w kulturze ludowej o tym, jaka kara spotka rolnika za pozostawienie narzędzi na polu ${ }^{42}$.

\section{ZADANIA DYDAKTYCZNE W PROCESIE EDUKACJI KULTURALNEJ}

Przekazując w katechezie orędzie wiary, trzeba być świadomym wartości tkwiących w kulturze narodowej. Należy też zdawać sobie sprawę, że zarówno kultura ludowa, jak i kultura rodziny, uformowana na podstawie kultury narodowej czy elementów kultury ludowej, zawiera wiele wartości wypływających z wiary katolickiej. Odwołując się do specyficznych właściwości tej kultury, łatwiej przekazać istotne elementy wiary chrześcijańskiej. Na pewno głębokie odniesienie do Boga i do świata przyrody ułatwiać może kształtowanie postawy zawierzenia Bogu. Kształtując etos pracy czy chrześcijańskie odniesienie do człowieka, możemy opierać się na wielu wytworach zarówno kultury narodowej, jak i kultury ludowej. Również eksponowanie rodziny w kulturze narodowej może ułatwiać przekazywanie katolickiej nauki o małżeństwie i rodzinie. $\mathrm{Z}$ drugiej strony lekcja religii ma szansę wypełnić rolę krytyczną wobec wielu form kultury narodowej czy ludowej, które ujawniają się w różnych obyczajach. Światło Ewangelii może pomagać w kształtowaniu biblijnego obrazu Pana Boga. Może też rozszerzać treść wiary, która funkcjonuje w kulturze ludowej. Zarazem lekcja religii musi nawiązywać do wartościowych obyczajów i zwyczajów, które kultywują wartości wypływające z wiary. Ona też powinna je wyjaśniać i inspirować do ich dalszego kultywowania.

Na katechezie trzeba też wykorzystać wiele okazji, aby przedstawić czy też przybliżyć wytwory polskiej kultury inspirowane wiarą katolicką. Warto zwrócić uwagę na tego typu utwory literackie, malarstwo, rzeźbę, architekturę kościelną, bogate zbiory pieśni religijnych wykorzystywanych w liturgii, jak też pieśni i piosenek katechetycznych. Godna uwagi jest także polska obrzędowość inspirowana zwłaszcza największymi świętami roku kościelnego czy religijnymi wydarzeniami przeżywanymi w rodzinie. Trzeba także pamiętać, że wiele wytworów tej kultury jest zupełnie niezrozumiałych

\footnotetext{
${ }^{42}$ Tamże, s. 89-90.
} 
dla młodego pokolenia. Stąd konieczne jest odkrywanie przed nimi znaczeń w nich zawartych.

Wielką szansę do tworzenia kultury inspirowanej wiarą daje uczestnictwo w życiu parafii. W wielu parafiach dość bogata oferta edukacyjna skierowana jest do różnych grup wiekowych. Dla dorosłych organizuje się katechezy przedmałżeńskie, podejmuje się działania zapobiegające alkoholizmowi i niesienie pomocy uzależnionym i ich rodzinom. W parafii istnieją chóry, które upiększają różne rodzaje nabożeństw. Do zakresu funkcji kulturalnej realizowanej przez nią zalicza się też pielgrzymki, które dają kontakt z dziełami kultury religijnej. Ponadto w wielu parafiach odbywają się projekcje filmów wideo, organizowane są także koncerty muzyczne, wystawy, inscenizacje, a także wyjazdy rekreacyjne. Tam można spotkać dość bogato wyposażone biblioteki parafialne, często wydaje się gazetki. W parafii świętuje się wydarzenia religijne, jak i ważne wydarzenia lokalne czy też upamiętnia się różne rocznice narodowe ${ }^{43}$.

Kultura niesie też ze sobą także wiele zagrożeń dla egzystencji człowieka, jak również dla wiary. Również kultura rodziny zawiera dziś wiele wytworów będących wynikiem tych zagrożeń. Realizując lekcje religii, trzeba sobie z tego zdawać sprawę i zapobiegać niekorzystnym zjawiskom. Postmodernizm przynosi ze sobą odrzucenie prawdy i dobra. Tym samym eksponuje agnostycyzm na płaszczyźnie poznawczej i zupełną dowolność zachowań w płaszczyźnie życia moralnego ${ }^{44}$. Z tym wiąże się, jak to podkreślił papież Jan Paweł II, banalizacja płci i bardzo upowszechnione współżycie seksualne oderwane od miłości (por. FC. 37). W takich okolicznościach wychowanie do czystości realizowane także na lekcjach religii spotyka się z brakiem zrozumienia ze strony szkoły i niektórych nurtów edukacji seksualnej ${ }^{45}$. Rodzina coraz częściej nie wprowadza w kulturę chrześcijańską i ulega obcym wpływom kulturalnym.

Współczesna kultura, przyjmująca postać indyferentyzmu religijno-moralnego, ma charakter nihilistyczny. W takiej perspektywie nie ma różnicy między racjonalizmem a irracjonalizmem, moralnością a niemoralnością, prawdą a kłamstwem, dobrem a złem. Wyzwolenie od prawdy spowodowało wyzwolenie od obowiązku i jakiegokolwiek ograniczenia. Człowiek może zatem żyć w sposób dowolny. Nie odczuwa obowiązku traktowania siebie i innych oraz całego świata w sposób odpowiedzialny. Życie staje się rodzajem zabawy. Może on bawić się życiem, korzystać z okazji i przyjemności. Obojętność wobec Boga

${ }^{43}$ Por. E. Chmielewska, Rola parafii w życiu społeczności lokalnej, w: Edukacja kulturalna w środowisku wsi i matego miasta, Warszawa 1997, s. 143-145.

${ }^{44}$ Por. J. Zabielski, Indyferentyzm religijno-moralny jako znamię wspótczesnej kultury chrześcijańskiej Europy, w: Drogi i rozdroża kultury chrześcijańskiej Europy, red. U. Cierniak, J. Grabowski, Częstochowa 2003, s. 561-571.

${ }^{45}$ Por. K. Skoczylas, Wychowanie do miłości w programie lekcji religii w gimnazjum, Studia Włocławskie 7 (2004), s. 199-215. 
prowadzi często do egzystencjalnej pustki i obojętności. Nie ma zasad, nie ma norm moralnych, nie ma też odpowiedzialności. Taki człowiek, bez korzeni, bez zasad, może myśleć i żyć, jak mu się podoba. Bezsens, będący udziałem ludzkiego życia, tworzy kulturę nicości, która jest w dalszej perspektywie kulturą śmierci ${ }^{46}$.

Katecheza musi też wziąć pod uwagę kulturę uczniów, zwłaszcza kulturę młodzieżową, która dziś jest w znacznym stopniu kształtowana przez telewizję. Telewizja wywołuje wśród widzów bezkrytyczny odbiór o niskiej selektywności. Ona też tworzy w świadomości odbiorców specyficzny obraz świata. Kształtuje też specyficzny sposób myślenia. Jest to myślenie telewizyjne, obrazkowe, z dominacją konkretnych skojarzeń. Dokonuje się też zubożenie języka. Jego cechą jest ubóstwo leksykalne, uproszczenie składni i redukcja przymiotników, które decydują o bogactwie i pięknie mowy. Zubożenie języka stanowi zagrożenie dla myślenia. W efekcie następuje zubożenie doświadczenia wewnętrznego. Zredukowane kategorie poznawcze zastępują bogate kategorie opisujące wewnętrzne procesy i działania. W konsekwencji zagrożony jest także przekaz doświadczenia wewnętrznego w kontaktach międzyosobowych. Programy telewizyjne wpływają także na emocjonalne odniesienie odbiorcy do siebie i świata. Kształtuje się emocjonalny styl, który wyraża się w nieskrępowanej ekspresji przeżyć, spontaniczności z równoczesnym osłabieniem świadomego chcenia. W produkcjach filmowych wykorzystuje się często emocje negatywne, takie jak: agresja, gniew, złość, zawiść, zazdrość i inne. Sytuacje przedstawiane w telewizji z dominacją negatywnych emocji powodują błędne wyobrażenie odbiorców o szerszym niż w rzeczywistości rozpowszechnieniu się przemocy w stosunkach międzyludzkich. A dzieci oglądające programy telewizyjne nasycone przemocą stają się obojętne wobec sytuacji przemocy pojawiających się w życiu codziennym ${ }^{47}$.

Lekcja religii, korzystając z dorobku kultury polskiej, kultury rodzin chrześcijańskich czy też z kultury ludowej, powinna stosować się jednocześnie do zasad określających proces inkulturacji. Orędzie chrześcijańskie trzeba coraz bardziej wprowadzać także w kulturę polską. Lekcja religii może być okazją do zapoznania wychowanków z wieloraką ofertą kulturalną parafii. Katecheta może zachęcić swoich uczniów do uczestnictwa w wielu formach aktywności kulturalnej w parafii. Katecheza musi także krytycznie oceniać wartości tkwiące w tej kulturze. Przekaz treści katechetycznych powinien uwzględnić dotychczasowy dorobek tej kultury, prowadzić do coraz głębszego jej rozumienia, wskazywać wartości pobudzające do jej tworzenia oraz inspirować do wyrażania w tej kulturze wartości wiary katolickiej. Przekazując treść orędzia ewangelicznego,

${ }^{46}$ Por. J. Zabielski, dz. cyt., s. 566.

${ }^{47}$ T. Ożóg, Kulturowe zagrożenia wychowania, w: Wychowanie chrześcijańskie a kultura, red. M. Nowak, T. Ożóg, Lublin 2000, s. 175-179. 
trzeba akcentować twórczy charakter wiary, który pomoże przezwyciężać nihilistyczne tendencje współczesnej kultury. Chrześcijaństwo, odwołując się do wzorów osobowych, może kształtować zaangażowane postawy, które pomogą przezwyciężać konsumpcyjny nurt kultury masowej, której najpowszechniejszym nośnikiem stała się telewizja. Może ona też stwarzać wiele okoliczności zachęcających do uczestnictwa w kulturze chrześcijańskiej.

\section{RELIGIONSUNTERRICHT UND KULTURELLERZIEHUNG}

\section{ZUSAMMENFASSUNG}

Eine Entwicklung des Menschen vollzieht nicht nur durch das schulische Unterrichten sondern auch durch das Kulturellerziehung, der umfasst eine ästhetische Erziehung, eine humanistische Erziehung und eine Erziehung die Teilnahme in der Symbolkultur ist. Eine Kultur ist auch ein Objekt des Interesses der Kirche, weil sie eine menschliche Person verbessern kann. Man es soll in der Bereich der Kultur auch eine christliche Kultur zu zahlen, dessen eine elementare Quelle eine Glaube ist. Die Katechese führt nicht nur in die Erkenntnis der Glaube aber auch in der nationale und christliche Kultur ein und er kann ein Anfang der inkulturation des Evangeliums zu sein. Eine Religionsstunde muss in Polen eine polnisch nationale Kultur berücksichtigen damit zu erleichtern junge Generation sich zu identifizieren sowohl mit der eigenen Nation als auch mit der Christenheit. Es soll auch ein Bewusstsein der Bedrohungen für die inkulturation des Evangelium haben und ihr zu entgegenzusetzen. 